\title{
Patterns of resource allocation to somatic, defensive, and reproductive functions in the Mediterranean encrusting sponge Crambe crambe (Demospongiae, Poecilosclerida)
}

\author{
Maria J. Uriz ${ }^{1, *}$, Xavier Turon ${ }^{2}$, Mikel A. Becerro ${ }^{1}$, Jordi Galera ${ }^{2}$, Javier Lozano ${ }^{2}$ \\ ${ }^{1}$ Centre d'Estudis Avançats de Blanes, Camí de Sta Bàrbara s/n, E-17300 Blanes (Girona), Spain \\ ${ }^{2}$ Departament de Biologia Animal, Universitat de Barcelona, Avda Diagonal, 645, E-08028 Barcelona, Spain
}

\begin{abstract}
The pattern of resource allocation in the sponge Crambe crambe (Schmidt) (Demospongiae, Poecilosclerida) in 2 contrasting habitats and in specimens of 3 size classes was studied. The sponge biomass per unit area increased with sponge size in both illuminated and dark environments. An increase with size was also found in the illuminated habitat for the investment in organic matter per unit area. This parameter was almost constant among the 3 size classes from the shaded habitat, with values similar to those of the medium-sized specimens from the illuminated environment. The amount of silica per $\mathrm{mm}^{2}$ was higher in the dark site where it proved size-dependent, whereas it did not vary with size in the illuminated habitat. Investment in reproduction per unit area was higher in the illuminated wall and was positively correlated with size in both habitats. The amount of calcareous debris included by the sponge during its growth did not vary across size classes in either habitat. All variables related to sponge thickness showed significant differences between the 2 sites studied, while neither the size nor the interaction of habitat and size significantly influenced their values. The specimens were thicker in the illuminated habitat, both in their choanosome and ectosome layers. No variations with size or site were found for the canal system. There was a significant habitat effect on the amount of matrix, which was higher in the illuminated environment. Sponges produced more collagen in the shaded environment than in the illuminated site. This was particularly true for specimens larger than $1000 \mathrm{~mm}^{2}$ (medium and large size classes). As for the number of fibres, there was also significantly more fibre material in the sciaphilous sponges. A significant interaction was found between habitat and size effects on the number of cells per sponge section. The pattern of resource allocation to the different functions considered was similar in medium-sized specimens from the 2 contrasting habitats except for the number of cells and amount of collagen per sponge section. Small and large sponges, on the other hand, featured the highest between-habitat differences in resource allocation. Large sponges from the illuminated habitat invested relatively more energy in organic matter and less in mineral and collagen structures than their sciaphilous counterparts. Small photophilic sponges invested more in silica than small sciaphilous specimens. Investment in reproduction was notably higher in the whole size range of photophilic sponges than in the corresponding size classes from the dark site. Consequently, this species seems able to shift its resource allocation as a function of size and environmental conditions. We propose an interpretation in terms of a higher competitive pressure in the shaded environment that results in increased investment in defensive/supportive (mineral and organic) structures and a lower investment in somatic growth (organic matter) and reproductive output (larvae).
\end{abstract}

KEY WORDS: Resource allocation - Reproductive investment - Silica · Organic matter · Collagen . Cells $\cdot$ Spongin $\cdot$ Sponges

\section{INTRODUCTION}

The patterns of resource allocation, from both physiological and life-history approaches, have been

•E-mail: iosune@ceab.es studied extensively in terrestrial plants (e.g. Rameau \& Gouyon 1991, Lerdau 1992, Mossop et al. 1994) and insects (e.g. Boggs 1992). Studies of this kind are much less frequent on marine benthic invertebrates (e.g. Hawkins et al. 1985), especially in the case of modular species, for which most of the references available deal 
with partial aspects of resource allocation (e.g. Hughes 1986, Barangé et al. 1989, Turon \& Becerro 1992, Comas 1994, Mistri \& Ceccherelli 1994), thus not yet allowing for general theories and models.

As in plants, internal rhythms strongly modulated by environmental factors are expected to cause shifts in resource allocation of benthic modular organisms. In temperate seas such as the Mediterranean, resource allocation is expected to vary following the seasonal pattern of the biological processes (Fell 1983, Sebens 1986) triggered by the cyclic variation of most key environmental factors, such as temperature, food availability, and photoperiod (Zabala \& Ballesteros 1989). Sexual reproduction is the most outstanding phenomenon among the possible biological functions showing a marked seasonality in modular invertebrates. Thus, it is a process to be taken into account when studies on resource allocation in sponges are performed.

We have studied the pattern of resource allocation of the ubiquitous, encrusting sponge Crambe crambe (Schmidt) in 2 contrasting habitats and in specimens of different size. Few studies have dealt with biomass allocation in sponges (Simpson 1968, Reiswig 1973. Elvin 1976). Variations in spicule contents have been documented for Chondrilla nucula (Bavestrello et al. 1993a), with maxima in spring and autumn, but no biological interpretation has been proposed to explain this seasonal variation. It has also been shown that the average size of sponge spicules varies cyclically over the period of a year (Stone 1970, Jones 1987a, b) and with depth (Bavestrello et al. 1993b). The spicule variation observed may be the result of differential resource allocation in these species as a function of size, habitat and season. The remaining data available on the total amount of silica stored by sponges are sporadic and gathered only for taxonomic purposes (Desqueyroux-Faundez 1990). Several studies also deal with the biochemical composition of sponges, related to their potential value as prey (Paine 1964, McClintock 1987), but variations in composition with sponge size and environmental conditions have not been described in such studies.

The sponge Crambe crambe displays different growth shapes related to size and habitat (Becerro et al. 1994). These morphological changes were thought to be modulated by encounters with different types of neighbours. The hypothesis of the present study was that these different growth shapes may also be related to differences in biological resource allocation. That is, those specimens with a marked directional growth caused by contact with neighbours that are strong competitors for the substratum (Becerro et al. 1994) would show shifts in their resource allocation towards defensive structures. Consequently, this study aimed to assess the relative allocation of materials and energy to different biological processes (i.e. somatic -- organic and mineral - vs reproductive investment) of this species as a function of size and in 2 contrasting habitats displaying different levels of competitive pressure to provide a better understanding of its life-history strategies

\section{MATERIAL AND METHODS}

Sampling was carried out in Blanes, NE Iberian Peninsula (western Mediterranean). The site was a 2 to $3 \mathrm{~m}$ wide, $40 \mathrm{~m}$ long gorge, running from east to west. Its rocky walls, facing north and south, respectively, were influenced by similar trophic and physical conditions, except for the amount of irradiance received (low in the north-facing wall, high in the south-facing one), which, consequently, determined the kind of community established there. (See Becerro et al. 1994 for a complete explanation of the site characteristics).

Specimens of Crambe crambe $(n=10)$ of 3 size categories were collected before the reproductive period (April 1992) by scuba diving from the illuminated and the shaded walls (a total of 30 specimens from each habitat). These 3 size categories were chosen because they had shown marked differences in growth shape during a previous study in which a wide range of sponge sizes was considered (Becerro et al. 1994) Their corresponding size ranges were - Class 1: specimens between 1 and $1000 \mathrm{~mm}^{2}$; Class 2: between 1000 and $10000 \mathrm{~mm}^{2}$; Class 3: more than $10000 \mathrm{~mm}^{2}$. A second series of 30 sponges (15 specimens from each habitat) was also collected in April 1992 and was used for histological examination (see below). A third series of 60 specimens ( 30 from each habitat) was collected in August 1992 for quantification of the sponge reproductive effort (larvae). To avoid any bias in the sampling, 3 points at each wall were randomly chosen, and then circular fields of increasing radii around these points were searched in a clockwise direction. All sponges encountered within these fields were sampled, until the desired final number for each size class and wall was reached.

Each individual of the first series was cut into 2 similar pieces, the surface areas of which were measured. Surface measurements were made by drawing the sponge contour on an acetate sheet covering the sponge surface. The area of these drawings was then calculated through a 'Genius' digitizer pad using the Hipad2 programme (written by K. Foreman of the Woods Hole Oceanographic Institution). All the sponge pieces were oven dried at $100^{\circ} \mathrm{C}$ to constant weight. One series of these dry pieces was used to measure the ash content. Ash was determined by plac- 
ing the dry specimens into a muffle furnace for $4 \mathrm{~h}$ at $500^{\circ} \mathrm{C}$. Organic matter (OM) content was calculated by subtracting the ash weight from the sponge dry weight. This can result in an overestimation of the OM according to Paine (1964), because the hydration water of the skeletal elements is lost during the tissue incineration, whereas it is still retained in the dry tissues. However, this possible overestimation is considered negligible given the relative scarcity of the siliceous skeleton in this sponge. The ash weight per $\mathrm{mm}^{2}$ was considered to represent mainly the amount of foreign debris (e.g. calcified endolithic cyanophyceae, tubes of small Polychaeta, and other calcareous debris) incorporated by the sponge, since the weight of the sponge spicules present was comparatively negligible. For the calculation of this spicule weight, the other series of sponge pieces was used. They were digested in nitric acid (Ruetzler 1978), and the residue (spicular material) was washed several times in distilled water and concentrated. The clean spicules were dried before weighing to ensure the total elimination of foreign water. The total sponge biomass was calculated as the sum of the organic (OM) and inorganic (siliceous) materials.

Partitioning of the organic materials. Since the above methods were unsuitable to distinguish among OM components, a completely different method based on microscopic observation of thick stained sections was developed in order to ascertain the relative contribution of collagen, fibres, matrix, and cell material to the sponge biomass.

Small fragments including the total sponge thickness were collected from the central part of 5 specimens of each size class in each habitat (totalling 30 sponges). They were fixed in formalin, embedded in paraffin and sectioned ( $5 \mu \mathrm{m}$ thickness) perpendicularly to the sponge surface at 3 different levels. Sections were stained according to Mallory's technique (Martoja \& Martoja 1970), which stains the collagen and spongin fibres in blue and the cells in a red or reddish colour. One section of those obtained from each level was selected for measurements ( $=3$ replicate readings per sponge). The whole section was recorded at low magnification $(40 \times)$ and digitized under a stereomicroscope which incorporated a video camera. Moreover, 2 separate images, one from the sponge choanosome and the other from the ectosome, were recorded at high magnification $(400 \times)$ using a light microscope with a video camera.

The digitized images were analysed using the program IMAT, developed at the University of Barcelona, working at a UNIX based workstation (Sun). By computing several binarizations of the images adjusting tonality, saturation, and intensity of colour, the program was able to distinguish cellular components, collagen, spongin fibers, intercellular matrix (collagen free), and aquiferous spaces. Due to a differential staining of the basal and distal portions, even in the same sponge section, different parameters were introduced in the binarization of images from each of the 2 layers. The following variables were recorded for each general view: total, choanosome and ectosome heights, porosity (measured as area of empty space/section area) and spongin fibres (area of fibres/section area). For each enlarged (choanosome or ectosome) view, we recorded collagen area/layer area, cell area/layer area, ratio collagen/cells, and matrix area/layer area. The variables for both layers were then combined in each section to give a global value by the formula

$$
Y\left(\mathrm{~S}_{\mathrm{s}}\right)=Y\left(\mathrm{~S}_{\mathrm{c}}\right) \frac{T_{\mathrm{c}}}{T_{\mathrm{t}}}+Y\left(\mathrm{~S}_{\mathrm{e}}\right) \frac{T_{\mathrm{e}}}{T_{\mathrm{t}}}
$$

where $Y\left(\mathrm{~S}_{\mathrm{s}}\right)$ is the value of the variable considered for the whole section, $Y\left(S_{c}\right)$ and $Y\left(S_{e}\right)$ are their values for the choanosome and ectosome sections, respectively, $T_{\mathrm{t}}$ stands for total thickness, and $T_{\mathrm{c}}$ and $T_{\mathrm{e}}$ for choanosome and ectosome thicknesses, respectively.

Upon examination of the sections, 3 sponges had to be discarded due to deficiencies in the processing. Three more sponges were later discarded from the data analysis because they presented values for 1 or more variables that were at least 1 order of magnitude outside the range encountered in the rest of sponges from all combinations of size and habitat. These were considered to represent rather particular and non-representative conditions of these sponge sections. Visual checking of box plots was performed to locate these outliers (Day \& Quinn 1989), and they were tested using Grubbs' statistic for outliers (Sokal \& Rohlf 1981) before being removed. All this introduced an inevitable inequality of sample sizes in the statistical analyses, but given the excessive time required to obtain the data, we preferred to include all the available information in an unbalanced design rather than discard more sponges to balance the data.

Reproduction. Reproductive investment was ascertained by examining the specimens under a stereomicroscope. Larvae were mainly located in the basal part of the sponge. We placed a plastic frame covering an area of $1.5 \mathrm{~cm}^{2}$ at random onto the sponge surface and scraped the sponge tissue of this area until the zone where larvae were present was reached. Larvae in an visual plane were counted, and the resulting number was multiplied by the thickness of the reproductive tissue divided by the mean diameter of 1 larva $(400 \mu \mathrm{m})$. Numbers of larvae were then translated into biomass units by means of a conversion factor calculated by weighing 300 lyophilised larvae together (1 larva $=45 \mu \mathrm{g}$ ). 
Statistical procedures. The values of the parameters studied were normally distributed and featured homogeneity of variances according to KolmogorovSmirnov and Barlett tests (Zar 1984), respectively, using the following transformations: angular transformation (ARCSIN) (Sokal \& Rohlf 1981) for organic matter, and rank transformation (RT; Akritas 1990 , Potvin \& Roff 1993) for total biomass, silica, collagen, cell, fibre, porosity, larva biomass, and ash-debris values. RT takes advantage of the properties of rank data, while at the same time allows the use of standard parametric methods (Potvin \& Roff 1993), which is especially useful if complex designs are to be applied.

For the analysis of total biomass, silica, organic matter ash-debris, and larvae, a 2-way analysis of variance was used, the factors being size ( 3 levels) and habitat ( 2 levels). The former is clearly a fixed factor, and the second must also be considered fixed, as the 2 communities studied were not selected at random but specifically chosen because they were a priori expected to differ (Bennington \& William 1993). We, therefore, restrict the conclusions to the communities present in these walls and to the size classes considered, and we do not intend to use the results as an estimate of the general variation among all possible habitats. Whenever we speak of an habitat effect, therefore, we refer exclusively to the 2 habitats considered. The analyses were performed using the procedures of the Systat version 5.0 package for balanced (biomass, organic matter, silica and ashdebris) and unbalanced (only on those specimens harbouring larvae) data.

The data from the histological sections were analysed using a design with 2 orthogonal fixed factors (habitat and size) and 1 nested random factor (specimen) with 3 to 5 levels (i.e. specimens studied) within each combination of the other 2 factors. A total of 3 replicate readings (i.e. sections) per specimen were used in the analyses.

Unplanned pairwise comparisons were performed following Ryan's $Q$ method (Einot \& Gabriel 1975, Day \& Quinn 1989), a stepwise procedure similar to the more familiar Student-Newman-Keuls (SNK) test, but which differs from it in the calculation of the adjusted alpha level at each step. This test is more conservative than the SNK test but is more powerful than the Tukey or Scheffé tests. Day \& Quinn (1989) compared the performance of several multiple comparison methods using Monte Carlo simulation and found that Ryan's $Q$ procedure produced the best approximation between the probability of Type I errors and the nominal alpha level. The overall alpha level for each set of multiple comparisons was set at 0.05 , and the harmonic mean of the sample sizes was used when the corresponding comparison was unbalanced (Day \& Quinn 1989).

When the interaction between main factors was significant, the levels of each factor were compared within levels of the other factor. The standard error of the comparisons (used in the computation of the corresponding $Q$ statistic) was calculated from the mean square (MS) in the denominator of the F-ratio used to test the effect of the interaction term in the overall ANOVA (Underwood 1981, Day \& Quinn 1989). This was the error MS in the 2-way design and the MS of the nested factor (specimen) in the 3-factor analyses. When the interaction was not significant in the overall ANOVA, and the test for any main effect proved to be significant, pairwise comparisons were made between levels of this factor across levels of the other (Zar 1984). The standard errors of the comparisons were computed from the MS in the denominator of the F-ratio corresponding to this factor in the overall ANOVA. (Underwood 1981). Significant effects of the specimen factor in the nested design led to no further comparisons, since this random factor was used to assess the variance associated with the different sponge specimens, and it was of no direct interest to determine which of the sponges had different means in any combination of the orthogonal factors.

Table 1. Crambe crambe. Two-way ANOVA for habitat and sponge size effects on sponge biomass, organic matter, silica, larvae, and foreign debris (ash) per $\mathrm{mm}^{2} F$-ratios and $\mathrm{p}$-values for main effects are indicated only if the interaction term is not significant

\begin{tabular}{|c|c|c|c|c|c|c|}
\hline & Source & SS & df & MS & $F$ & $\mathrm{p}$ \\
\hline Sponge biomass & $\begin{array}{l}\text { Habitat } \\
\text { Size } \\
\text { Habitat } \times \text { Size } \\
\text { Error }\end{array}$ & $\begin{array}{r}349.338 \\
3268.400 \\
280.686 \\
13200.588\end{array}$ & $\begin{array}{r}1 \\
2 \\
2 \\
54\end{array}$ & $\begin{array}{r}349.338 \\
1634.200 \\
140.343 \\
249.067\end{array}$ & $\begin{array}{l}1.402 \\
6.561 \\
0.563\end{array}$ & $\begin{array}{l}0.241 \\
0.002 \\
0.572\end{array}$ \\
\hline Organic matter & $\begin{array}{l}\text { Habitat } \\
\text { Size } \\
\text { Habitat } \times \text { Size } \\
\text { Error }\end{array}$ & $\begin{array}{l}0.011 \\
0.059 \\
0.059 \\
0.283\end{array}$ & $\begin{array}{r}1 \\
2 \\
2 \\
54\end{array}$ & $\begin{array}{l}0.011 \\
0.029 \\
0.029 \\
0.005\end{array}$ & 5.661 & 0.005 \\
\hline Silica & $\begin{array}{l}\text { Habitat } \\
\text { Size } \\
\text { Habitat } \times \text { Size } \\
\text { Error }\end{array}$ & $\begin{array}{r}0.339 \\
1508.796 \\
3671.275 \\
1.1813 .122\end{array}$ & $\begin{array}{r}1 \\
2 \\
2 \\
54\end{array}$ & $\begin{array}{r}0.339 \\
754.398 \\
1835.637 \\
222.889\end{array}$ & 8.235 & $<0.001$ \\
\hline Larvae & $\begin{array}{l}\text { Habitat } \\
\text { Size } \\
\text { Habitat } \times \text { Size } \\
\text { Error }\end{array}$ & $\begin{array}{r}265.850 \\
1207.421 \\
72.233 \\
1533.633\end{array}$ & $\begin{array}{r}1 \\
2 \\
2 \\
28\end{array}$ & $\begin{array}{r}265.850 \\
603.710 \\
36.116 \\
54.722\end{array}$ & $\begin{array}{r}4.853 \\
11.022 \\
0.659\end{array}$ & $\begin{array}{r}0.035 \\
<0.001 \\
0.525\end{array}$ \\
\hline Foreign debris & $\begin{array}{l}\text { Habitat } \\
\text { Size } \\
\text { Habitat } \times \text { Size } \\
\text { Error }\end{array}$ & $\begin{array}{r}146.066 \\
18.300 \\
17058.200 \\
13200.588\end{array}$ & $\begin{array}{r}1 \\
2 \\
2 \\
54\end{array}$ & $\begin{array}{r}416.066 \\
9.150 \\
251.216 \\
315.892\end{array}$ & $\begin{array}{l}1.317 \\
0.028 \\
0.795\end{array}$ & $\begin{array}{l}0.256 \\
0.971 \\
0.456\end{array}$ \\
\hline
\end{tabular}




\section{RESULTS}

\section{Biomass}

A significant effect of size on the sponge biomass per surface unit ( $p=0.002$ ) was detected by the 2-way ANOVA analysis, whereas neither the habitat effect nor the interaction were significant $(p=0.24, p=0.57$. respectively; Table 1). Post hoc multiple comparisons (Ryan's $Q$ tests at an overall 0.05 alpha level between size classes pooled across habitats) showed that large sponges were responsible for the size effect: sponges of more than $10000 \mathrm{~mm}^{2}$ contained significantly more biomass per surface unit than small and medium-sized sponges. These values ranged from $0.22( \pm 0.07) \mathrm{mg}$ $\mathrm{mm}^{-2}$ in Class 1 (sciaphilous specimens) to 0.34 ( \pm 0.08$)$ $\mathrm{mg} \mathrm{mm}^{-2}$ in Class 3 (photophilic specimens) (Fig. 1A).

\section{Organic matter}

The interaction between size and habitat effects was significant ( $p=0.005$ ) (Table 1$)$, indicating a different trend with size in the 2 habitats studied. Pairwise comparisons (Ryan's $Q$ at $\alpha=0.05$ ) between size classes failed to detect significant differences among the sciaphilous sponges. In contrast, a significant size effect was found in the illuminated habitat, due to the high values featured by large sponges (which were significantly different from the small and mediumsized specimens). Photophilic sponges larger than $10000 \mathrm{~mm}^{2}$, on the other hand, invested significantly more energy in organic matter than their sciaphilous counterparts. (The remaining pairwise comparisons among habitats at fixed size levels were not significant.)

The organic matter contents per surface unit increased from $0.16( \pm 0.025) \mathrm{mg} \mathrm{mm} \mathrm{mm}^{-2}$ in the smallest sponges to $0.29( \pm 0.029) \mathrm{mg} \mathrm{mm}^{-2}$ in the largest sponges from the illuminated habitat. This parameter was almost constant among the 3 size classes from the dark habitat with a value of about $0.2 \mathrm{mg} \mathrm{mm}^{-2}$, similar to that of the medium-sized specimens from the illuminated habitat (Fig. 1B).

\section{Silica content}

The interaction between size and habitat showed a significant effect on the amount of silica $(p<0.001)$ (Table 1), Ryan's $Q$ tests between size classes in the 2 habitats showed significant differences among the 3 size classes from the dark habitat (the 3 pairwise comparisons were significant), whereas all comparisons were not significant in the illuminated habitat. Photo-
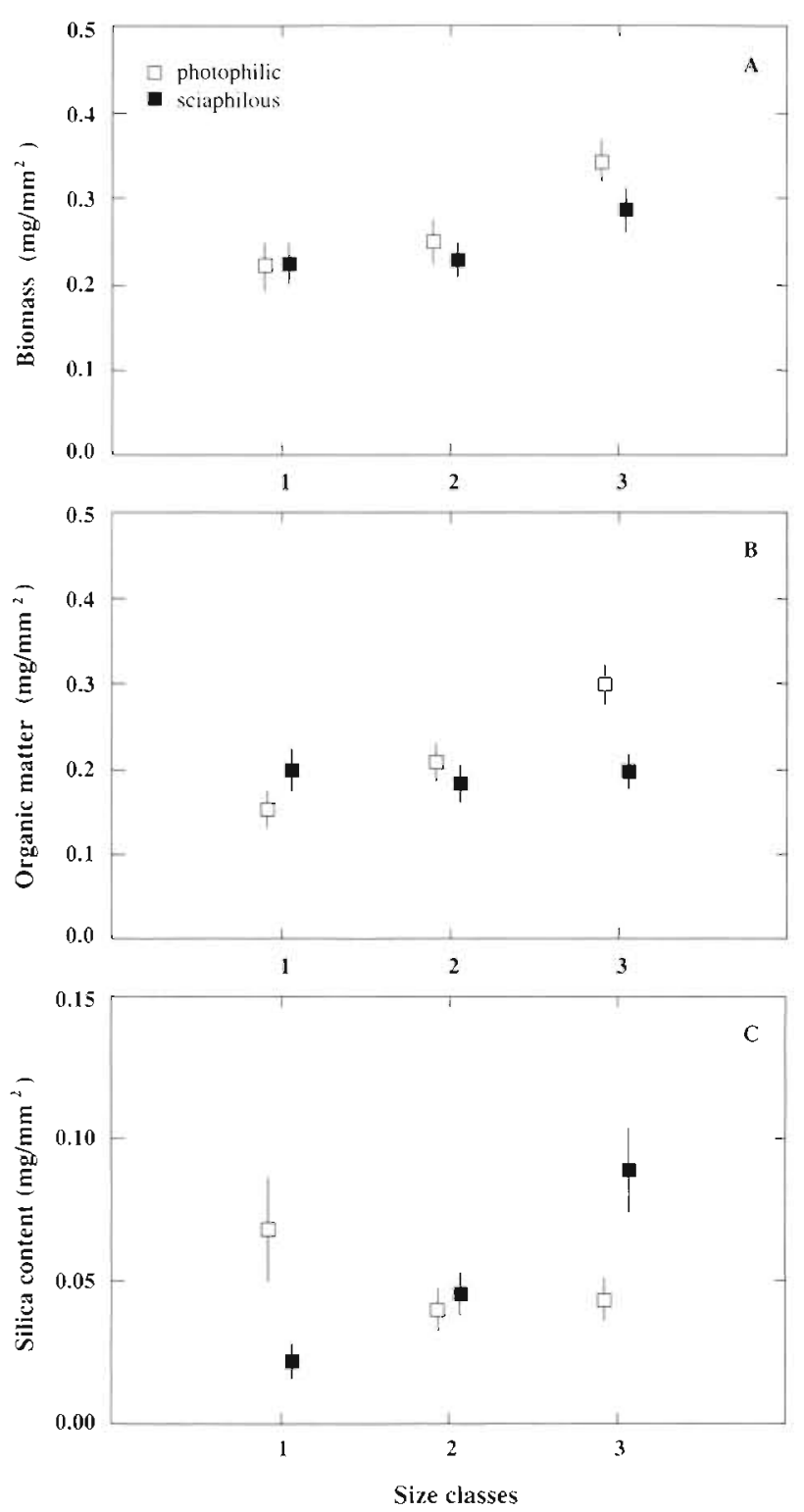

Fig. 1 Crambe crambe. Mean ( $\pm \mathrm{SE}$ ) values of the (A) sponge biomass, ( $B$ ) organic matter and (C) silica content per surface unit as a function of size in the 2 habitats studied. Size class 1 : sponges $<1000 \mathrm{~mm}^{2}$ in area; Size 2: sponges between 1000 and $10000 \mathrm{~mm}^{2}$; Size 3: sponges $>10000 \mathrm{~mm}^{2}$

philic sponges smaller than $1000 \mathrm{~mm}^{2}$ contained significantly more silica per surface unit than their sciaphilous counterparts, whereas sciaphilous sponges larger than $10000 \mathrm{~mm}^{2}$ invested more in silica than photophilic specimens of the same size class.

In the shaded environment, the investment in $\mathrm{SiO}_{2}$ $\mathrm{mm}^{-2}$ increased linearly with sponge size. It was much lower in sponges of Class $1\left(0.015 \pm 0.007 \mathrm{mg} \mathrm{mm}^{-2}\right)$, and reached values of $0.08( \pm 0.004) \mathrm{mg} \mathrm{mm} \mathrm{mm}^{-2}$ in the largest sponges (Fig. 1C). These values were 2 -fold 
higher in sciaphilous than in photophilic large sponges. The 3 photophilic size classes invested a similar amount of silica to that of the medium-sized sciaphilous specimens.

\section{Relative investment in organic and mineral structures}

The amount of siliceous material was always much lower than the organic matter. The percentage of the sponge biomass (dry weight) corresponding to silica ranged in this species from $4 \%$ in large photophilic sponges to $18 \%$ in small photophilic sponges. These values were 7,10 and $12 \%$, respectively, for small, medium and large sponges from the dark habitat.

\section{Organic materials partitioning}

The values of organic matter obtained by subtracting the ash values from the total biomass values include different organic materials that may account for different biological functions (i.e. cells and structural proteins). The different contribution of these organic components to the total sponge organic matter was assessed by estimating their relative proportion in spange sections (see 'Materials and methods').

Two different cell layers of variable thickness depending on species can be clearly differentiated in all the known demosponges: the ectosome, at the sponge periphery, which has a mainly protective function (Simpson 1984), and the choanosome, in the inner part, where the main biological functions are performed (e.g. water pump, food capture and reproduction). The ectosome of Crambe crambe is a collagenenriched layer with relatively few cells, consisting mainly of pinacocytes, collencytes and spherulous cells. The choanosome contains endopinacocytes, choanocytes, archeocytes, sclerocytes and spongocytes together with some scattered spherulous cells close to the canals (Becerro 1994).

Tables 2 \& 3 show the results of the 3 -factor ANOVA of the variables studied in the sponge sections (total thickness, choanosome thickness, ectosome thickness, porosity, matrix area, spongin fibre area, collagen area, cell area, and the ratio between collagen and cells). It can be seen that the specimen factor was significant for all variables, indicating a noticeable variability among individuals.

All variables related to sponge thickness showed significant differences between the 2 walls studied, while neither the size factor or the interaction between size and habitat featured a significant effect in the analysis. The sponges were thicker in the illuminated habitat, both for the choanosome and the ectosome layers (Fig. 2).

No variations with the factors considered were found for the porosity (Fig. 3A). There was a significant habitat effect on the amount of matrix, which was higher in the illuminated environment (Fig. 3B) As for the

Table 2. Crambe crambe. Three-factor ANOVA for size, habitat and specimen effects on total sponge thickness, choanosome and ectosome thickness, and porosity per sponge section

\begin{tabular}{|c|c|c|c|c|c|c|}
\hline & Source & SS & $\mathrm{df}$ & MS & $F$ & $\mathrm{p}$ \\
\hline \multirow[t]{5}{*}{ Sponge thickness } & Habitat & 11018.767 & 1 & 11018.767 & 18.355 & $<0.001$ \\
\hline & Size & 978.695 & 2 & 489.347 & 0.815 & 0.458 \\
\hline & Habitat $\times$ Size & 1466.531 & 2 & 733.265 & 1.221 & 0.318 \\
\hline & Specimen & 10805.900 & 18 & 600.328 & 7.753 & $<0.001$ \\
\hline & Error & 3562.083 & 46 & 77.436 & & \\
\hline \multirow[t]{5}{*}{ Choanosome thickness } & Habitat & 11664.43 & 1 & 11664.432 & 21.262 & $<0.001$ \\
\hline & Size & 201.480 & 2 & 100.740 & 0.184 & 0.834 \\
\hline & Habitat $\times$ Size & 2701.904 & 2 & 1350.952 & 2.463 & 0.113 \\
\hline & Specimen & 9874.674 & 18 & 548.598 & 6.970 & $<0.001$ \\
\hline & Error & 3620.666 & 46 & 78.710 & & \\
\hline \multirow[t]{5}{*}{ Ectosome thickness } & Habitat & 3474.036 & 1 & 3474.036 & 4.458 & 0.049 \\
\hline & Size & 723.897 & 2 & 361.939 & 0.464 & 0.636 \\
\hline & Habitat $\times$ Size & 0.402 & 2 & 0.201 & 0.000 & 0.999 \\
\hline & Specimen & 14026.972 & 18 & 779.276 & 3.444 & $<0.001$ \\
\hline & Error & 3620.666 & 46 & 78.710 & & \\
\hline \multirow[t]{5}{*}{ Porosity } & Habitat & 1305.250 & 1 & 1305.250 & 1.688 & 0.210 \\
\hline & Size & 477.857 & 2 & 238.928 & 0.309 & 0.738 \\
\hline & Habitat $\times$ Size & 982.688 & 2 & 491.344 & 0.636 & 0.541 \\
\hline & Specimen & 13915.263 & 18 & 773.070 & 3.520 & $<0.001$ \\
\hline & Error & 9883.833 & 46 & 219.640 & & \\
\hline
\end{tabular}


Table 3. Crambe crambe. Three-factor ANOVA for size, habitat and specimen effects on matrix, fibres, collagen, and cells per sponge section, and on the ratio collagen/cells. F-ratios and p-values for main effects are indicated only if the interaction term is not significant

\begin{tabular}{|c|c|c|c|c|c|c|}
\hline & Source & SS & $\mathrm{df}$ & MS & $F$ & $p$ \\
\hline Matrix & $\begin{array}{l}\text { Habitat } \\
\text { Size } \\
\text { Habitat } \times \text { Size } \\
\text { Specimen } \\
\text { Error }\end{array}$ & $\begin{array}{r}6982.809 \\
980.091 \\
956.509 \\
9742.729 \\
9718.666\end{array}$ & $\begin{array}{r}1 \\
2 \\
2 \\
18 \\
46\end{array}$ & $\begin{array}{r}6982.809 \\
490.045 \\
473.254 \\
541.263 \\
211.275\end{array}$ & $\begin{array}{r}12.901 \\
0.905 \\
0.874 \\
2.562\end{array}$ & $\begin{array}{l}0.002 \\
0.422 \\
0.434 \\
0.005\end{array}$ \\
\hline Spongin fibres & $\begin{array}{l}\text { Habitat } \\
\text { Size } \\
\text { Habitat } \times \text { Size } \\
\text { Specimen } \\
\text { Error }\end{array}$ & $\begin{array}{r}3833.767 \\
4080.441 \\
834.950 \\
8351.673 \\
6668.667\end{array}$ & $\begin{array}{r}1 \\
2 \\
2 \\
17 \\
43\end{array}$ & $\begin{array}{r}3833.767 \\
2040.220 \\
417.475 \\
491.275 \\
155.085\end{array}$ & $\begin{array}{l}7.804 \\
4.153 \\
0.850 \\
2.875\end{array}$ & $\begin{array}{l}0.012 \\
0.034 \\
0.445 \\
0.003\end{array}$ \\
\hline Collagen & $\begin{array}{l}\text { Habitat } \\
\text { Size } \\
\text { Habitat } \times \text { Size } \\
\text { Specimen } \\
\text { Error }\end{array}$ & $\begin{array}{r}3815.333 \\
211.712 \\
5206.423 \\
13253.566 \\
5627.833\end{array}$ & $\begin{array}{r}1 \\
2 \\
2 \\
18 \\
46\end{array}$ & $\begin{array}{r}3815.333 \\
105.856 \\
2603.211 \\
736.309 \\
122.344\end{array}$ & $\begin{array}{l}5.182 \\
0.114 \\
3.535 \\
6.018\end{array}$ & $\begin{array}{r}0.035 \\
0.867 \\
0.051 \\
<0.001\end{array}$ \\
\hline Cells & $\begin{array}{l}\text { Habitat } \\
\text { Size } \\
\text { Habitat } \times \text { Size } \\
\text { Specimen } \\
\text { Error }\end{array}$ & $\begin{array}{r}103.375 \\
1921.634 \\
7804.695 \\
11582.667 \\
4795.333\end{array}$ & $\begin{array}{r}1 \\
2 \\
2 \\
18 \\
46\end{array}$ & $\begin{array}{r}103.375 \\
960.817 \\
3902.347 \\
643.482 \\
104.246\end{array}$ & $\begin{array}{l}6.064 \\
6.173\end{array}$ & $\begin{array}{r}0.010 \\
<0.001\end{array}$ \\
\hline Collagen/cells & $\begin{array}{l}\text { Habitat } \\
\text { Size } \\
\text { Habitat } \times \text { Size } \\
\text { Specimen } \\
\text { Error }\end{array}$ & $\begin{array}{r}2162.452 \\
610.637 \\
7712.923 \\
11484.548 \\
5398.666\end{array}$ & $\begin{array}{r}1 \\
2 \\
2 \\
18 \\
46\end{array}$ & $\begin{array}{r}2162.452 \\
305.318 \\
3856.461 \\
638.030 \\
117.362\end{array}$ & $\begin{array}{l}6.044 \\
5.436\end{array}$ & $\begin{array}{r}0.010 \\
<0.001\end{array}$ \\
\hline
\end{tabular}

number of fibres, the factors habitat and size proved significant, and the interaction was not. There was significantly more fibre material in the sciaphilous sponges. This was particularly evident for the smallest size class (Fig. 3C). Only the means of the small and medium-sized sponges (habitats pooled) differed significantly in the post hoc comparisons (Ryan's Q).

A global effect of habitat ( $p=0.035$ ) was found for the amount of collagen per sponge section, with the sponges from the shaded environment displaying a higher investment in collagen. This effect seems to be due mostly to the medium and large-sized specimens (Fig. 4A). In contrast, the habitat effect on the number of cells per sponge section was conditional on sponge size (the interaction between size and habitat was significant at $p=0.01$ ). Levels of each main factor were therefore compared (Ryan's Q) at fixed levels of the other factor. The medium-sized sponges from the illuminated environment had significantly more cells than the corresponding size class in the shaded environment (Fig. 4B). The reverse is true for the smallest size class. No significant differences for this variable were detected between sizes in the shaded wall, while in the illuminated habitat, the medium-sized specimens contained more cellular matter than the small sponges.
As for the relative investment in collagen and cellular elements, a significant interaction term $(p=0.01)$ indicated a different trend of this ratio with size in each habitat (Fig. 4C). Multiple comparisons (Ryan's $Q$ at $\alpha=0.05$ ) between habitats for each size class showed that the medium-sized sciaphilous specimens had a higher collagen/cells ratio than their photophilic counterparts. No size differences were detected within the sponges from the sciaphilous community, while in the illuminated habitat the only significant comparison was between small and medium-sized specimens, the former featuring a higher ratio.

\section{Reproduction}

Investment in reproduction was examined in early August, when the percentage of specimens containing mature larvae was at its highest. These percentages were 20,50 and $100 \%$ in photophilic sponges of Classes 1, 2 and 3, respectively, whereas in the dark habitat the percentages were 10,70 and $80 \%$, respectively.

A 2-way ANOVA showed a significant effect of size $(p<0.001)$ and habitat ( $p=0.03$ ) on the sponge reproductive investment (only sponges in reproduction were included in the analysis; Table 1). No significant inter- 

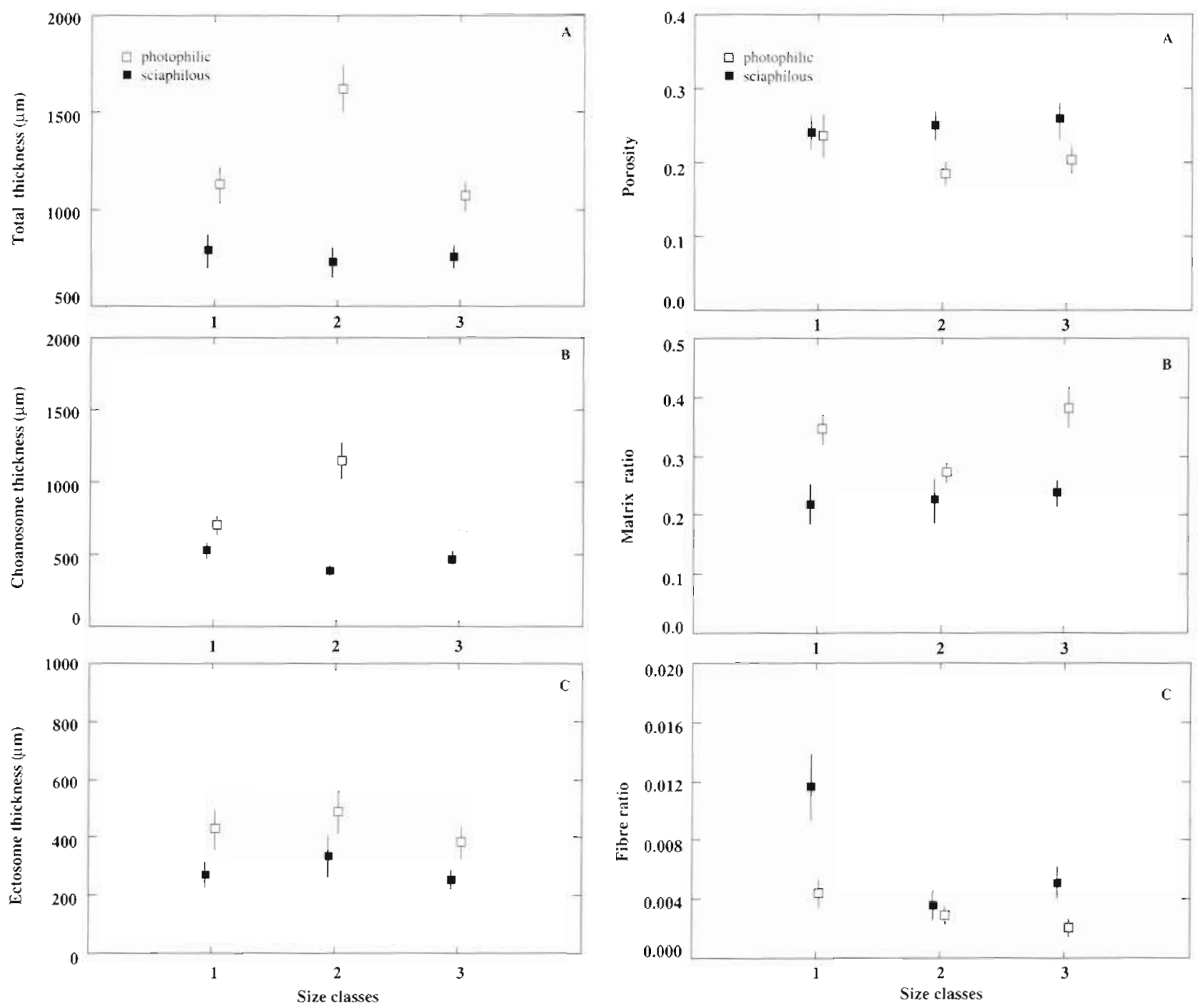

Fig. 2. Crambe crambe Mean ( $\pm \mathrm{SE}$ ) values of the (A) total sponge thickness, (B) choanosome thickness and (C) ectosome thickness as a function of size in the 2 habitats studied. (Size classes as in Fig. 1)

Fig. 3. Crambe crambe. Mean ( $\pm \mathrm{SE}$ ) values of the (A) porosity. (B) matrix area and (C) fibre area per sponge section area as a function of size in the 2 habitats studied. (Size classes as in Fig. 1)

action between effects was detected $(p=0.52)$. Post hoc tests between sizes indicated that the sponges larger than $10000 \mathrm{~mm}^{2}$ were responsible for the size effect (pairwise comparisons of this size class with the other 2 were significant). Investment in reproduction per surface unit was higher in the photophilic sponges (ranging from $0.004 \pm 0.0018$ to $0.009 \pm 0.0017 \mathrm{mg} \mathrm{mm}^{-2}$ with increasing sizes) than in those from the dark habitat (from 0.000 to $0.0078 \pm 0.002$ ) (Fig. $5 \mathrm{~A}$ ).

\section{Ash contents (foreign debris)}

The ash values per surface unit, corresponding almost exclusively to foreign calcareous debris, did not

vary across size classes $(p=0.97)$ nor across habitats $(p=0.25)$ as analysed by a 2-way ANOVA test (Table 1$)$. The interaction term was also not significant. However, the standard error was notably higher in sponges from the shaded habitat than in the photophilic sponges. This reflects a higher variation in the presence of these inclusions in the former environment (Fig. 5B).

\section{DISCUSSION}

The species Crambe crambe grows comparatively thicker in the illuminated habitat irrespective of its size, and this applies to both the choanosome and the ectosome layers. No variations were found for the develop- 


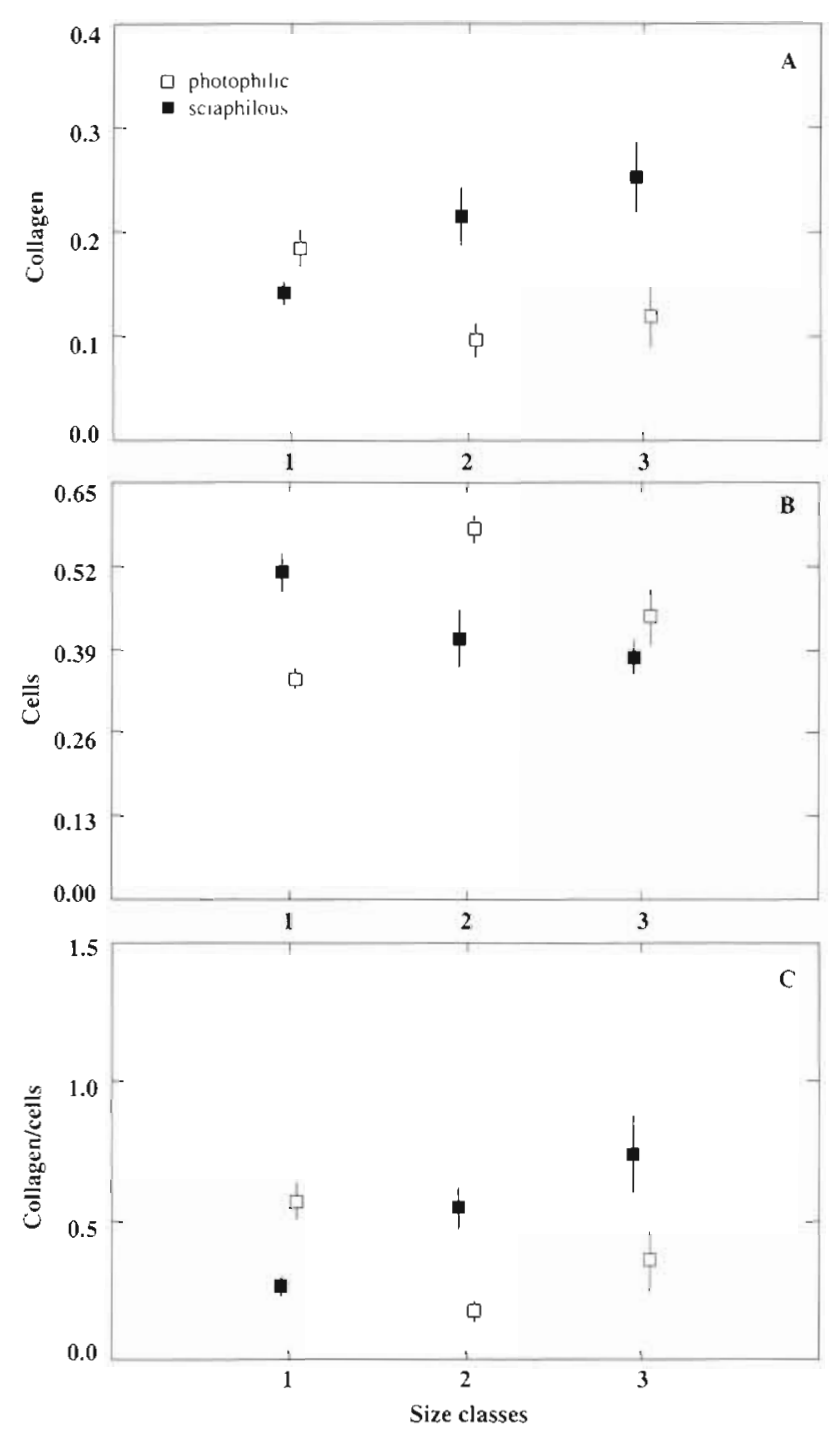

Fig. 4. Crambe crambe. Mean ( \pm SE) values of the (A) collagen area, $(B)$ cells area and $(C)$ the ratio collagen/cells per sponge section area as a function of size in the 2 habitats studied (Size classes as in Fig. 1)

ment of the canal system (porosity). Therefore, the differences in thickness could not be attributed to varying degrees of contraction of the sponge but corresponded to differences in the amount of sponge material.

Irrespective of the habitat considered, the sponge total biomass (dry weight) per unit area increased with sponge size only beyond a certain size (i.e. from $10000 \mathrm{~mm}^{2}$ on). At smaller sizes, it is conceivable that the sponges' strategy could be directed to occupying as much substratum as possible with a given biomass. Investment in organic matter per surface unit increased with sponge size in the illuminated environment, while it remained invariable in the dark site. Large photophilic sponges display more organic mat-
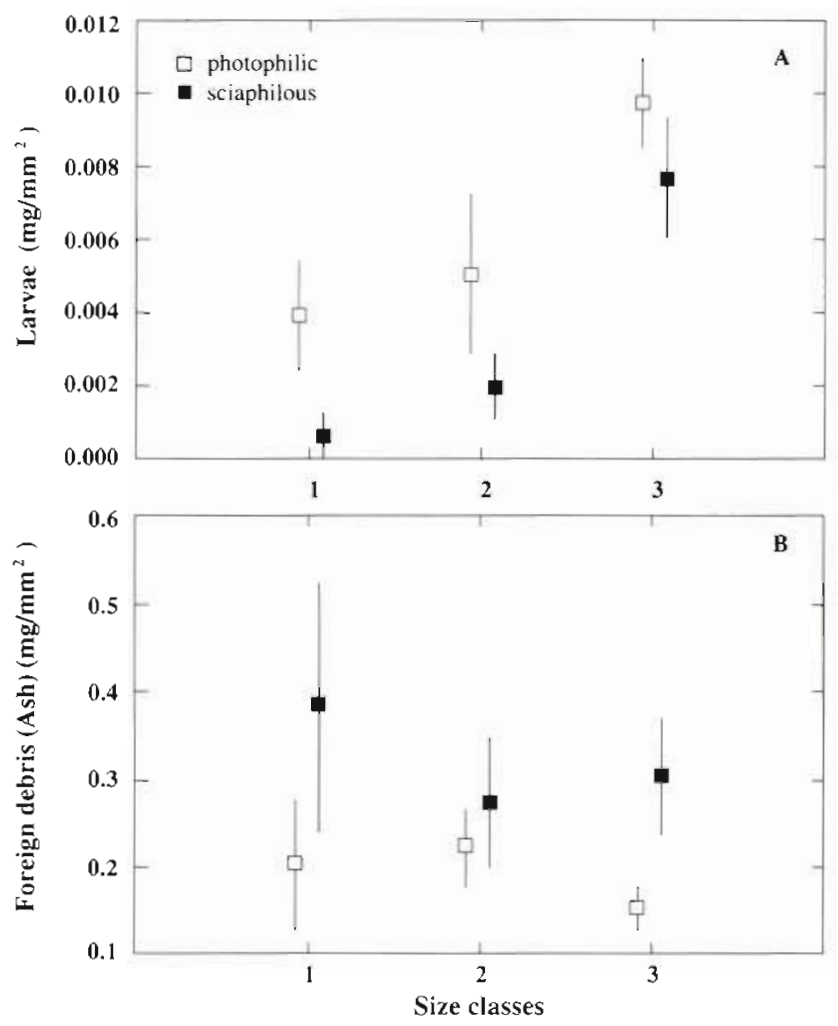

Fig. 5. Crambe crambe. Mean ( \pm SE) values of the (A) larvae dry weight and $(B)$ foreign debris (ash content) per sponge surface unit as a function of size in the 2 habitats studied. (Size classes as in Fig. 1)

ter per unit area than large sciaphilous sponges. On the contrary, investment in silica per unit area increased across the 3 size classes in the shaded site, while it did not vary with size in the illuminated habitat. Thus, organic matter, which can be considered an indicator of the somatic growth, accounted for the higher biomass per unit area of the large photophilic sponges, whereas silica accounted for the higher biomass of the large sponges in the dark habitat.

There was a noticeable variability among individuals in the variables studied in the sponges' sections, as shown by a significant specimen effect in the nested analyses. This result was to be expected, since other factors, besides size and type of habitat [e.g. genetic factors, sponge age (not always correlated with size), and physiological state] can be envisaged to influence the structural composition of the sponges. Nevertheless, the nested design used for the analyses of these data allowed testing for the effect of the levels of the factors of interest after taking into account the variance associated with the individuals (nested factor) (Sokal \& Rohlf 1981, Underwood 1981).

The amount of matrix, which is related to the activity of the cells (Simpson 1984), was significantly higher in 
the photophilic sponges, whereas investment in longlasting materials such as spongin (fibres) and collagen was higher in the sciaphilous sponges. It seems that small sciaphilous specimens invest more in spongin than medium and large specimens, which, conversely, invest more in collagen. The medium-sized sponges from the illuminated environment, on the other hand, had more cellular material than the corresponding size class in the dark environment. The reverse was true for the smaller size class.

The trend of the ratio between investment in collagen and cellular material with size was different in each habitat. The low collagen/cell ratio displayed by medium-sized photophilic specimens and also by small sciaphilous specimens seems to indicate a faster growth of these specimens, since collagen materials display lower renovation rates than cells (Simpson 1984).

Although the amount of organogenic calcareous debris included by the sponge during its growth did not vary across size classes in either habitat, the standard error was notably higher in the sciaphilous sponges than in the photophilic ones. This may reflect a lack of selection of these debris by sponges of any size and a higher variation in the number of these organisms in the sciaphilous environment

As a whole, small and medium-sized specimens $\left(<10000 \mathrm{~mm}^{2}\right)$ behave as young forms which have not yet reached the optimum patch size to guarantee success against the remaining competitors for the substratum (Sebens 1986). After a certain size is reached, the sponge grows in a third dimension (photophilic sponges) or concentrates its biomass by investing in supportive materials such as collagen or spicules which, additionally, may have a defensive function (sciaphilous specimens).

As in other modular organisms (Szmant-Froelich 1985), reproductive investment was positively correlated with size. Such a significant relationship was found in both habitats studied, although, in general, sponges from the illuminated environment invested more in reproduction than their counterparts from the dark habitat. Some experimental studies in plants support theoretical predictions that suggest that competition should have a major negative effect on reproductive allocation (Bazzaz et al. 1987). Thus, in crowded, highly competitive habitats, such as those of the shaded site studied (Becerro 1994, Becerro et al. 1994), high fecundity rates might decrease the competitive abilities of space accupation and maintenance of Crambe crambe.

Biomass allocation to different functions (vegetative growth, support and defence structures, reproduction) in Crambe crambe can be interpreted under the resource based perspective (Mossop et al. 1994) which states that resources are limiting and that reproduc- tion, growth, and defence interact within individuals and compete for these limited resources, so that any additional investment in one function must be at the expense of the remainder.

The ecological distribution of Crambe crambe in the western Mediterranean (e.g. Boury-Esnault 1971, Uriz et al. 1992) highlights the photophilic nature of this species. In fact, it is the most abundant sponge species in fleshy algae-dominated communities. This suggests that this species was closer to its ecological optimum in the well-illuminated habitat studied than in the shaded wall. The favourable environmental conditions encountered by the photophilic specimens may explain their higher investment in organic matter and reproduction. The differences in reproductive investment may also be influenced by the fact that sciaphilous specimens featured a thinner choanosome. Since the larvae are incubated only in this region, their number could be limited by the reduced space available. This would be an example of non-nutritional constraints resulting in limited opportunities for reproduction, which have also been considered to affect patterns of resource allocation (Boggs 1992).

All abiotic environmental conditions except light were similar in both habitats. It should be noted that no photosynthetic symbionts were found in the many specimens from this site studied at the optical and ultrastructural level (Becerro 1994), and thus no metabolic advantages attributable to symbionts are envisaged for these photophilic sponges. Moreover, no predators of this toxic, highly unpalatable species are known (Becerro 1994) in either of the 2 habitats studied. It is unlikely, therefore, that abiotic factors or predation pressure could determine the pattern of resource allocation found. Space competition pressures may be a key factor influencing the resource allocation in this sponge. The sciaphilous assemblage studied featured a marked space limitation and was dominated by long-lived, substratum-dependent animal species (Becerro et al. 1994), while the illuminated habitat was dominated by fleshy seaweeds with short life cycles, with patches of bare substratum being regularly produced. It seems likely, therefore, that sciaphilous sponges devote more energy to spatial competition. The different growth shapes exhibited by this species in different habitats (Becerro et al. 1994) also highlight such diverse competition pressures, which may also account for the quantitative differences in toxic production detected for this species in the study area (Becerro 1994), toxicity values being in general higher in the sciaphilous environment.

The overall lower figures of reproduction and organic matter per surface unit and the higher values of collagen and spicules found in sponges of the dark habitat fits the hypothesis of an increase in investment 
in supporting and defensive structures or chemical defences, at the expense of somatic growth and reproduction, as a response to spatial competition. Structural or morphological defences are commonly associated with an anti-predatory function (e.g. Pennings \& Paul 1992, Van Alstyne et al. 1994), but they have also been described as defensive means against damage from neighbouring organisms (Sammarco et al. 1985). In fact, defensive and support functions are difficult to separate in sessile organisms such as sponges. If a support function were the only role of spicules, collagen and fibres, one would expect to find higher amounts of these in the '3-dimensional' photophilic specimens, which are more vulnerable to breakage. However, this was not the case. Most probably both functions (defence and support) are performed by the same structures in the case of Crambe crambe.

As in the case of shape parameters (Becerro et al. 1994), the differences in relative investment become more evident in larger sponges. Large specimens from both habitats showed more clearly an increased investment in organic matter (illuminated habitat) or siliceous, and collagen material (shaded habitat). The similar silica content of the photophilic sponges of any size (no significant differences among size classes were found) may reflect basic structural needs for sponge organization in this habitat. In contrast, this investment was lower in small sciaphilous specimens. An adaptive response of the young sponges to space limitation may be a fast initial growth, with little investment in presumably costly (its production involves highly active secretory cells\}, long-lasting spicular materials. Once the available space has been colonized, an increased investment in structural materials with size would be a response to the size-dependent competition pressures faced by the sponge. Nevertheless, knowledge on the physiology and biology of the first states of growth in sponges is almost non-existent; therefore, interpretations of this different trend in biomass allocation exhibited by the smallest sponges are inevitably somewhat speculative at present.

In conclusion, the pattern found correlates well with the optimal resource allocation theory, which states that energy is devoted to organic material production and reproduction unless special needs divert the investment towards structural and defensive elements (in our case, possibly as a response to space competition pressures). The investment of this sponge in siliceous structures ( 4 to $18 \%$ dry wt) is lower than those found in Antarctic (32 to $72 \%$ dry wt; McClintock 1987 ) and in tropical siliceous sponges (4.5 to $57.3 \%$ dry wt $_{i}$ Desqueyroux-Faundez 1990). However, other non-mineral materials (collagen and spongin fibres), providing structural support and toughness to the sponge, as well as toxic compounds (Jares-Erijman et al. 1991, Berlink et al. 1992, Martín \& Uriz 1993, Becerro et al. 1995) account for the global investment in structural/defensive functions of this species.

Nevertheless, the interpretation proposed here must be considered with care since the data obtained arose from different methods of quantification, and, in some cases, display different degrees of precision. Moreover, resource input and the cost of constructing and maintaining the different sponge materials are difficult to estimate and were beyond the scope of the present study. Thus, our intention was not to obtain a metabolic balance from the data gathered but rather to present a first approach which allows for the detection of shifts in resource allocation in this species in the 2 contrasting habitats as a function of size.

Acknowledgements. The authors are indebted to J. M. Tur, who helped in the field work. The Spanish Marine Resources and Aquaculture Programme (project CICYT MAR91-0528) and the Commission of the European Communities (project MAST-CT91-004) provided funds for this research. The Basque Government provided financial support to M.A.B.

\section{LITERATURE CITED}

Akritas MG (1990) Two-factor designs. J Am statist Ass $85(409): 7378$

Barangé M, Zabala M, Riera T, Gili JM (1989) A general approach to the in situ energy budget of Eudendrium racemosum (Cnidaria, Hydrozoa) in the Western Mediterranean. Scientia mar 53:423-427

Bavestrello G, Bonito M, Sarà M (1993a) Silıca content and spicular size variation during an annual cycle in Chondrilla nucula Schmidt (Porifera, Demospongia) in the Ligurian sea. In: Uriz MJ, Ruetzler $K$ (eds) Recent advances in ecology and systematics of sponges. Sci Mar, Barcelona, p 415-420

Bavestrello G, Bonito M, Sarà M (1993b) Influence of depths on the size of sponge spicules. In: Uriz MJ, Ruetzler K (eds) Recent advances in ecology and systematics of sponges. Sci Mar, Barcelona, p 421-425

Bazzaz FA, Chiariello NR, Coley PD, Pitelka LF (1987) Allocating resources to reproduction and defense. BioSci $37(1): 58-67$

Becerro MA (1994) Chemically mediated bioactivity of the encrusting sponge Crambe crambe and its ecological implications. PhD thesis, Univ of Barcelona

Becerro MA, Uriz MJ, Turon X (1994) Trends in space occupation by the encrusting sponge Crambe crambe: variation in shape as a function of size and environment. Mar Biol 121:301-307

Becerro MA, Uriz MJ, Turon X (1995) Measuring toxicity in marine benthic environments: critical appraisal of three commonly used methods. Experientia 51:414-418

Bennington CC, William VT (1993) Use and misuse of mixed model analysis of variance in ecological studies. Ecology 75(3):717-722

Berlinck R, Braekman JC, Daloze D, Bruno I, Riccio R, Rogeau D. Amade P (1992) Crambines C1 and C2: two further ichthyotoxic guanidine alkaloids from the sponge Crambe crambe. J nat Prod 55(4):528-532 
Boggs CL (1992) Resource allocation: exploring connections between foraging and life history. Funct Ecol 6:508-518

Boury-Esnault N (1971) Spongiaires de la zone rocheuse littorale de Banyuls-sur-Mer. I. Ecologie et répartition. Vie Milieu 22(1):159-192

Comas R (1994) Evaluación del balance energético de dos especies de cnidarios bentónicos marinos. PhD thesis, Univ of Barcelona

Day RW, Quinr GP (1989) Comparisons of treatments after an analysis of variance in ecology. Ecol Monogr 59(4):433-463

Desqueyroux-Faundez R (1990) Silica content of the New Caledonian fauna of Haplosclerida and Petrosida and its possible taxonomic significance. In: Ruetzler K (ed) New perspectives in sponge biology. Smithsonian Institution Press, Washington, DC, p 279-283

Einot I, Gabriel KR (1975) A study of the power of several methods of multiple comparisons. J Am statist Ass 70:574-583

Elvin DW (1976) Seasonal growth and reproduction of an intertidal sponge, Haliclona permollis (Bowerbank). Biol Bull 151:108-125

Fell PE (1983) Porifera. In: Adiyodi KG, Adiyodi RG (eds) Reproductive biology of invertebrates, Vol I. John Wiley \& Sons Ltd, New York, p 1-29

Hawkins AJS, Salkeld PN, Bayne BLE, Gnaiger E, Lowe DM (1985) Feeding and resource allocation in the mussel Mytilus edulis: evidence for time-averaged optimization. Mar Ecol Prog Ser 20:273-287

Hughes RG (1986) Differences in the growth, form and life history of Plumularia setacea (Ellis and Solander) (Hydrozoa: Plumulariictae) in two contrasting habitats. Proc R Soc Lond (Ser B) 288:113-125

Jares-Erijman EA, Sakai R. Rinehart KL (1991) Crambescidins: new antiviral and cytotoxic compounds from the sponge Crambe crambe J org Chem 56:5712-5715

Jones WC (1987a) Seasonal variations in the skeleton and spicule dimensions of Haliclona elegans (Bowerbank) sensu Topsent (1887) from two sites in North Wales. In: Jones WC (ed) European contributions to the taxonomy of sponges. Litho Press, Middleton, p 109-129

Jones WC (1987b) Skeletal variation in embryo-containing specimens of Haliciona rosea (Bowerbank) from Anglesey, North Wales. In: Vacelet J, Boury-Esnault N (eds) Taxonomy of Porifera. Springer-Verlag, Berlin, p 101-124

Lerdau M (1992) Future discounts and resource allocation in plants. Funct Ecol 6:371-375

Martín D, Uriz MJ (1993) Chemical bioactivity of Mediterranean benthic organisms against embryos and larvae of marine invertebrates. J exp mar Biol Ecol 173:11-27

Martoja R, Martoja M (1970) Técnicas de histología animal Toray Masson, Barcelona

McClintock JB (1987) Investigation of the relationship between invertebrate predation and biochemical composition, energy content, spicule armament and toxicity of benthic sponges at McMurdo Sound, Antarctica. Mar Biol $94: 479-487$

Mistri M. Ceccherelli VU (1994) Growth and secondary production of the Mediterranean gorgonian Paramuricea clavata. Mar Ecol Prog Ser 103:291-293

Mossop R, Macnair MR, Roberson AW (1.994) Within-population variation in sexual resource allocation in Mimulus

This article was submitted to the editor guttatus. Funct Ecol 8:410-418

Paine RT (1964) Ash and calorie determınations of sponge and opisthobranch tissues. Ecology 45(2):384-387

Pennings SC, Paul VJ (1992) Effect of plant toughness, calcification and chemistry on herbivory by Dolabella auricularia. Ecology 73(5):1606-1619

Potvin C, Roff DA (1993) Distribution-free and robust statistical methods: viable alternatives to parametric statistics? Ecology 74(6):1617-1628

Rameau C, Gouyon PH (1991) Resource allocation to growth, reproduction and survival in Gladiolus: the cost of male function. J evol Biol 4:291-307

Reiswig HM (1973) Population dynamics of three Jamaican sponges. Bull mar Sci 23:191-226

Ruetzler K (1978) Sponges in coral reefs. In: Stoddart DR, Johannes RE (eds) Coral reefs: research methods. Monographs on oceanographic methodology 5. UNESCO, Paris, p 299-313

Sammarco PW, Coll JC, La Barre S (1985) Competitive strategies of soft corals (Coelenterata: Octocorallia). Il. Variable defensive responses and stability to scleractinian corals. J exp mar Biol Ecol 91:199-215

Sebens K (1986) Spatial relationships among encrusting marine organisms in the New England subtidal zone. Ecol Monogr 56(1):73-96

Simpson TL (1968) The biology of the marine sponge, Microciona prolifera. II. Temperature-related annual changes in functional and reproductive elements with a description of larval metamorphosis. J exp mar Biol Ecol 2:252-277

Simpson TL (1984) The cell biology of sponges. SpringerVerlag, New York

Sokal RR, Rohlf FJ (1981) Biometry, 2nd edn. WH Freeman and Company, New York

Stone AR $(1970)$ Seasonal variations in spicule size in Hymeniacidon perleve. J mar biol Ass UK 50:343-348

Szmant-Froelich AM (1985) The effect of colony size on the reproductive ability of the Caribbean coral Montrastrea annularis (Ellis and Solander). Proc 5th int Coral Reefs Congr 4:295-300

Turon X, Becerro MA (1992) Growth and survival of several ascidian species from the northwestern Mediterranean. Mar Ecol Prog Ser 82:235-247

Underwood AJ (1981) Techniques of analysis of variance in experimental marine biology and ecology. Oceanogr mar Biol A Rev 19:513-605

Uriz MJ, Rosell D, Martín D (1992) The sponge population of the Cabrera archipelago (Balearic Islands): characteristics, distribution and abundance of the most representative species. PSZN I: Mar Ecol 113(2):101-117

Van Alstyne KL, Wylie CW, Paul VJ (1994) Antipredator defenses in tropical Pacific soft corals (Coelenterata: Alcyonacea). II. The relative importance of chemical and structural defenses in three species of Sinularia. J exp mar Biol Ecol 178:17-34

Zabala M, Ballesteros E (1989) Surface-dependent strategies and energy flux in benthic marine commnunities or why corals do not exist in the Mediterranean. Scienita mar $53: 3-7$

Zar JH (1984) Biostatistical analysis, 2nd edn. Prentice-Hall, Englewood Cliffs, NJ

Manuscript first received: December 6, 1994 Revised version accepted: February 16, 1995 